\title{
USA's Crusade on the Haitian Black Pig Population \& its Toll on Haitian Peasantry and Agriculture Sarah Taluy
}

Sarah Taluy is a graduate of the University of Toronto. She completed her Hon. Bachelors of Arts in 2013 with a specialist in Caribbean Studies, a major in International Relations and a minor in Spanish. Currently, Sarah is pursuing a Masters Degree at the London School of Economics and Political Science (LSE) in International Development and Humanitarian Emergencies. In the future, she aspires to contribute to improving Haitian relations with the rest of the Caribbean and take part in research that she hopes will bring about real development in her country and positively affect the lives of Haitians.

On January $12^{\text {th }} 2010$, a surrounding city of Port-au-Prince (PAP) was hit by 7.0 magnitude earthquake. In the end a staggering 300,000 casualties had been reported and millions were displaced. The event was perhaps the most catastrophic calamity to strike Haiti, since its "discovery" in 1492. The earthquake further exacerbated the hardships of day-to-day lives of Haitians suffering from isolation and imperialistic policies. The fact that an earthquake had such a devastating impact on the country was closely linked to the weak and inefficient infrastructure but more importantly for the purposes of this paper to the ineffective and poor peasantry. The agricultural sector in Haiti in the 1950's employed about $80 \%$ of the population and by the 1980 's, declined to $66 \%$ of the population. ${ }^{1}$ Therefore, it is safe to say that a majority of Haitians were heavily reliant on agriculture. However, Haiti's agricultural production has suffered dramatically as a result of the implementation of free trade prescriptions and the introduction of economic liberalization policies under the auspices of institutions like the International Monetary Fund and World Bank, which ultimately limited the ability of the Haitian state to govern and help its own population.

Those in the countryside continue to suffer the most from these decisions that prohibit government subsidies or any such aid. This setback coupled with the American led slaughter of the Haitian native pig, also known as Creole Pig, the cochon planche or the black

\footnotetext{
${ }^{1}$ Richard A. Haggerty, Haiti: A Country Study, Country Studies (Washington: GPO for the Library of Congress, 1989). http://countrystudies.us/haiti/54.htm
} 
pig, in 1982-3 completely destroyed the composition of the agricultural system in Haiti. As a result, poverty in rural Haiti has drastically intensified and consequently there has been an exodus from rural areas to the capital. This led to the overcrowding of PAP and the building of unstable structures directly causing the death toll in the January 2010 to be of astronomical proportions. In order to understand the over-population of Port-au-Prince and the high number of casualties from the 2010 earthquake, I will argue that US foreign policy in the early 1980's towards Haiti, had stunted the agricultural development in Haiti by destroying the fundamental fabric of the peasantry system- the Haitian black pig, and ultimately further entrenched the maladies of the poverty stricken countryside.

Haiti, part of the island of Hispaniola, was the first black colony to forcefully attain independence from the French forces of Napoleon Bonaparte. This was remarkable because, at a time where French armies were defeating all major European forces, they suffered a defeat by enslaved forces that were not as well trained and armed. On January $1^{\text {st }} 1804$, the efforts of Toussaint L'Ouverture and later Jean-Jacques Dessalines among others came to fruition and Haiti was declared a free Republic. Haiti's independence has been stifled since its inception. Haiti was forced to pay France 90,000,000 Francs as repatriation and a guarantee not to be invaded by French armies. Thereafter, Haiti also experienced several US military occupations. It has been 208 years now since the independence of Haiti and unfortunately the majority of these years have been plagued by dire poverty, violence, and corruption. The causes of these misfortunes have varying sources from internal to external roots and most of the times, a combination of both. Haiti's government and politics have been marred by violence and corruption and it appears that although government regimes may have switch hands, so did the intensity of violence and poverty. Haiti was invaded and occupied by the United States of America (USA) from 1915-1934 due to a period of intense political violence and a US fear for its corporations in Haiti. In the late 1950's, perhaps the most notorious government of Haiti took office: the Duvalier regime beginning in 1957 with Francois Duvalier and ending with the overthrow of his son Jean-Claude Duvalier in 1986. It is during the tenure of the second repressive and brutal dictatorship that the black pig disaster occurred amidst increasing liberalization.

It would be a mistake to think that it was only while the Duvaliers were in power that the Haitian peasantry had been 
neglected. "The Haitian state has always been authoritarian from Dessalines to the two Duvaliers, Haiti has known nothing but dictators" and most, neglected its peasants and instead, worried about maintaining power more than anything else. ${ }^{2}$ Prior to the Duvalier era, Paul Magloire ruled Haiti. Magloire had put a tax on coffee, Haiti's main export, which had raised the coffee price by $16 \%$ in 1953 and by $1955^{-56}$ it had increased to $27 \%$ thus putting the fate of the peasantry in the stock exchange market where any price decrease would directly affect the cultivators. ${ }^{3}$ In the mid 50's discontent towards the Magloire regime grew to unprecedented heights and led him to free Haiti in 1956. An election ensued in 1957 but high priority matters were not given to the rural parts of Haiti, only the cities mostly Port-au-Prince were paid attention to; Michel Trouillot observed that even though the agricultural sector accounted for the largest portion of the GNP, they were marginalized during the election, and were not even recognized as the backbone of the Haitian economy and thus, the peasantry's efforts were negated. ${ }^{4}$ François Duvalier, like Magloire, put a tax on another of Haiti's export crops, sugar. The tax collected on sugar grew to 37\% in 1969 and instead of the government re-investing in the agricultural sector in order to generate growth and improve the agricultural and irrigation systems, the redistribution of wealth was divided between three useless parts of Haitian society the "parasites, individual gains, and buying sympathisers." 5 Duvalier was thus pocketing the profits from the hard labour of the peasants and to bribe the allegiance of people to remain in power and rule through a system of fear and extreme brutality where even women, children and elders were not spared from the violence pursued by his loyal army the Tonton Macoutes. Although after the Duvalier period violence slightly decreased, the neglect of the agricultural sector persisted and its' depreciation continued.

As previously stated, Haiti's main source of employment post-independence was within the agricultural sector. In CLR James' Black Jacobins, the leader of the revolution saw very early the importance of agriculture in the development of Haiti; "Toussaint saw early that political power is only a means to an end. The

\footnotetext{
2 Michel-Rolph Trouillot, State Against Nation: The Origins and Legacy of Duvalierism (New York: Monthly Review Press, 1990). 164

3 Ibid. 143

4 Ibid. 147

5 Trouillot, 154
} 
salvation of San Domingo lay in the restoration of agriculture.... Toussaint addressed himself to this from the first days of his command. Work is necessary, it is a virtue, it is for the general good of the state." 6 By the 1980's, although the percentage of peoples employed in the agricultural sector had declined, it was still the major employer, accounting for some $66 \%$ of the population. ${ }^{7}$ The Haitian peasantry organized in a very novel manner, one that differed from other economic systems, this unique system was known as Kombit. ${ }^{8}$ Kombit is a practice relying on agriculture and the sharing rather than selling of services and goods; there is no money involved in these exchanges and the system is based on the community gathering to harvest and then sharing the products. ${ }^{9}$ The typical Kombit will have a planter announce the harvest day and invite the neighboring community to come and help in the cultivation process, there, the tasks will be divided depending on gender and capability, and all while working, chants of encouragements can be heard alongside jovial conversation. ${ }^{10}$ The Haitian Kombit promoted self-sufficiency encouraged the consumption of locally produced and exchanged goods, but not the exportation of goods. ${ }^{11}$ This practice was very well described in Jacque Roumain's novel Gouverneurs de la Rosée where the protagonist Manuel led a Kombit to reunite the town and helped in finding water to assist in the cultivation of crops. The practice of Kombit, a promoter of unity and cooperation, was what had saved the town from drought, division amongst families, and more poverty. Laurent Dubois writing on Jacques Roumain's Masters of the Dew, stated that the novel's crux is to promote Haiti's rural population by putting it at the centre of a story rather then on the sidelines; Dubois argued that Roumain tried to make a connection between the elite world of Haiti, which he belonged to, and "the core foundation of his country: the farmers and families of the countryside" this goes hand

\footnotetext{
${ }^{6}$ C.L.R. James, The Black Jacobins, Second Edition (New York: Vintage Books Edition, 1989). 155-56

7 Haggerty.

8 Roland Berthold, Kombit a Haitian agricultural and economic system, http://www.haitimega.com/Agricultural_Products_and_Practices-

Kombit_a_Haitian_agriculture_and_economic_system/85543180715950112/ article_86195166922211328.jsp (accessed 2012 -04-04).

9 Ibid.

10 Berthold.

11 Ibid.
} 
and hand with CLR James' argument concerning Toussaint and his promotion of agriculture previously mentioned. ${ }^{12}$

Apart from the Kombit, Haitian peasants also cultivated land under a system known as méteyage or dimouatyé. In this system the peasantry would turn over half of their produce to their landowner and the other half would remain for personal use.13 Dimouatyé is similar to the notion of renting a piece of the land but more often then not, the amount of land being rented is not specified and no concrete contract is signed, however, if the landlord was to take his land back, he would be responsible to pay the tenant farmer the cost of cultivation if it had already occurred. ${ }^{14}$ This system provided Haitian peasants with the liberty to choose what they wanted to cultivate and also allowed for a monetary-free exchange that enabled many of those affected by poverty to engage in a system of collateral exchange. ${ }^{15}$ Although Haitian peasants were highly neglected and used very basic tools such as the hoe, the machete, the sickle, the digging stick and the fork, this method of collateral exchange, along with state support would have been beneficial to adequately meet the demands of this local system. ${ }^{16}$

The Haitian black pig was the peasant's most valued asset it served as a local banking system, had a central role in Vodou ceremonies and was also an important source of protein. ${ }^{17}$ Pigs were a promising investment for peasants as by killing or selling them they were able to meet their household obligations, finance their children's schooling, healthcare, baptisms, funerals, weddings, and other unexpected expenses and also protected them from the city

\footnotetext{
12 Laurent Dubois, Haiti: The Aftershocks of History (New York: Metropolitan Books Hentry Hold and Company,LLC, 2012). 309

13 Serge Larose, L'exploitation Agricole en Haiti: Guide d'etude (Montreal: Centre de Recherche Caraibes, University of Montreal, 1976). 43

14 Larose,, 14

15 Dubois, 269

16 Larose, 49

17 Paul Farmer, "Swine Aid," in THe Haiti Files: Decoding the Crisis, ed. James Ridgeway, 130-133 (Washington D.C: Essentiaal Books, 1994). 130 AND Patrick Bellegarde-Smith, Haiti: The Breached Citadel (Toronto: Canadian Scholar's Press Inc., 2004). 47 AND Franz C. M. Alexander, "Experience with African Swine Fever in Haiti," Annals of the New York Sciences, June 1992: 251-256. 255
} 
loan sharks. ${ }^{18}$ The Creole pig was also very cost efficient since it needed no care, roamed freely, ate whatever they found and during famines would live off their grease. ${ }^{19}$ In religious Vodou ceremonies the sacrifice of a Haitian black pig was very important, this practice dates back to the ceremony that took place before the first slave revolt led by Boukman where at "Morne Rouge, a mountain overlooking le cap, Boukman gave the last instructions and after Voudou incantations and the sucking of the blood of a stuck pig he stimulated his followers by a prayer..." ${ }^{20}$ It was believed that the blood of the black pig sealed contracts during Vodou rituals. ${ }^{21}$ Aside from religious and economic purposes, because the caring of the Black pig was so minimal, they thrived under the worst circumstances and when there was a famine; their meat could be used as source of protein for the peasants and Haitian population itself. It is believed that $50 \%$ of the protein intake of Haitians was satisfied by the black pig, explaining the traditional dish of the fried pieces of pork known as Griots. ${ }^{22}$

In 1978, African swine fever (ASF), an incurable and fast spreading disease that affected pigs causing hemorrhagic fevers and in a short amount of time leads to death, began flourishing across the Americas. ${ }^{23}$ The disease was caused by an atypical DNA virus that easily spreads through a host tick called tampans. For example, when pigs are in close contact with each other, these tampans spread and pullulate and thus, infect them through the sucking of their blood. ${ }^{24}$ ASF was endemic to the southern and central parts of Africa but has

\footnotetext{
18 Farmer, 130-133 (Washington D.C: Essentiaal Books, 1994). 130 AND Rod Price, Haiti Family Business. London: Latin American Bureau (Research and Action) Limited, 1985.47

19Debora MacKenzie, "Haiti, le retour du cochon," Pyepimanla, http://www.pyepimanla.com/decembre-2008/articles/haiti-le-retour-ducochon.html (accessed 02 4, 2012).

20 C.L.R. James, "The San Domingo Masses Begin," in Caribbean Slavery in the Atlantic World: A Student Reader, ed. Hilary McD. Beckles Verene Shepherd, 946-960 (Kingston: Ian Randle Publishers Limited, 2000). 947 21 Mohamed Larbi Bouguerra, Pour Sauver le Cochon Noir d'Haiti, http://www.pyepimanla.com/decembre-2008/articles/haiti-le-retour-ducochon.html (accessed 01 21, 2012).

22Bellegarde-Smith, 207.

23 Food and Agriculture Organization of the United Nations, "Recognizing African

Swine Fever: A field Manual," FAO Corporate Document Repository, 2000, http://www.fao.org/DOCREP/004/X8060E/X8060E00.HTM\#ch2 (accessed 03 31, 2012).

24 Ibid.
} 
been known to infect swine in Europe in rare occasions. It was through infecting pigs in Europe that this virus spread to the Caribbean region. In 1978, pigs in the Dominican Republic, 2/3 of the island that Haiti shares, ate contaminated (ASF) pig wastes from the meals that had been served aboard a flight arriving from Europe. (ASF virus cannot spread to humans so the meat of an infected pig will not cause a human to be sick). ${ }^{25}$ From the Dominican Republic, ASF spread to Cuba and Haiti. Once ASF was detected in the Americas, the USA led an investigation into the Haitian pigs and found that a small number of pigs had been infected however; many appeared to be resistant to the disease because not many infected pigs actually died as the disease predicted. ${ }^{26}$ Haiti's native pig was a small but robust descendant of the European pig of the XVII century whose diet consisted of whatever it found in the area.27 After discovering that some Haitian pigs were infected with ASF, the USA chose to protect its own pig industry and funded the $\$ 23$ million Programme pour L'Éradication de la Peste Porcine et pour le Dévelopment de l'Évlevage Porcine (PEPPADEP) which would serve to exterminate and restock the swine population. ${ }^{28}$ USAID and the Haitian government had thus promised to compensate the peasants for the slaughter of their pigs, whether infected or not, through the importation of new pigs. The reimbursement plan did not prove as efficient as the eradication program had been. Many Haitians did not get reimbursed and those that did quickly realized the inefficiency of the newly brought pigs. ${ }^{29}$

Haiti being only an hour and a half flight away from USA's Florida could not escape the American ASF pillaging. The USA did everything in its power to protect its own self-interests, without a care about the adverse effects it would have on the Haitian peasantry. They had to make sure that their own farmers would not stand to lose with the spread of ASF and thus convinced the Haitian government to slaughter its domestic pig population that stood at 1.3 million in 1981. Thus, by 1984, there remained no Haitian black pigs on the island. ${ }^{\circ}$ The US Agency for International Development Aid (USAID) had argued that the only way to successfully eradicate ASF

\footnotetext{
25 MacKenzie.

26 Farmer, 130

27 MacKenzie

28 Farmer, 130

29 Dubois, 325

30 Farmer, 130-1
} 
was to kill all of the pigs and as Laurent Dubois argued, this was perhaps the first time that the Haitian government efforts towards any policy aimed at rural Haiti was so successful because this brutal attack on the peasantry and its native pig had devastating effects in innumerable facets of Haitian life. The killing of all of the Haitian pigs was not necessarily the best solution because ASF specialists recommended pinpointing the ASF infected animals and only slaughtering those infected. ${ }^{31}$ During the period when ASF was present on the island, the USAID funded PEPPADEP and had international veterinarians come and train local Haitian veterinarians in order to carry out the mass slaughter. One of the veterinarians who helped in the detection and eradication process Franz C.M. Alexander admitted that out of the slaughter of 34,488 pigs, only $2 \%$ had been infected by ASF. ${ }^{2}$ With that being said, would it not have been simpler to test the pigs and kill those who were infected instead of devastating a whole population? Unfortunately, the USA chose eradication rather than preservation of the black pig and thus, the former represented the best option. The USA believed that if ASF reached their country they would stand to loose $\$ 560$ million while eradicating ASF would only cost them $\$ 300$ million a year for a decade therefore, the swine population in the neighboring island, Hispaniola, had to be dually annihilated to make sure that the US did not get infected. 33

The eradication of ASF and the Haitian pig population affected many different sectors of Haiti. Not only was the main source of protein completely demolished but the possibility of maintaining avenues of fast cash had also disappeared. Immediate signs of concern appeared just two months after the USA had declared Haiti free of ASF on August of 1984.34 In the 1980's and early 1990's the school year began in October and in October of 1984, school registration had plummeted some 40-50\%; those businesses which provided books, cloth and uniform makers, school supply stores as well as other businesses felt the economic slowdown. 35 Religious rites in Vodou had to be altered because there were no more black pigs, causing a high demand for black pigs to preserve

\footnotetext{
31 Bouguerra.

32Alexander, 255

33 MacKenzie

34 Farmer,131

35 Ibid.
} 
culture and respect rituals. ${ }^{36}$ The loss of the pig had wider repercussions outside of the financial and nutritional realm, as peasants now had an excess of mangoes previously used to feed the pigs. In order to perpetuate more cash flow the mangoes were sold at the market and mango trees were used to make charcoal - as an attempt to replace the loss of the pig with a new type of business. 37 Haiti had already begun to suffer from deforestation and the use of mango trees to sell as charcoal further aggravated the situation. As an alternative to the breeding of the Haitian pig, peasants began breeding goats, which also thrived in Haiti however; the goat also further inflamed the deforestation problem since they feed on small shrubs and any vegetation and thus would hinder any attempts of replanting trees..$^{8}$ The problem of deforestation is enormous in Haiti, in 1923, Haiti's forests made up 60\% of the country and recently, in 2006 it was said to stand at only $2 \%$ ! 39 This massive decrease has been the source of numerous deadly landslides and has caused the deterioration of the soil leading to lower agricultural yields. 40

The USAID funded PEPPADEP had planned to compensate the Haitian peasants and to re-stock Haiti with new pigs and of course, went directly to its own swine farmers and exported 500 Iowa pigs to Haiti.41 This species did not fare very well in the hot and poor environment. This newly introduced pig excluded the peasants from the pig industry because Iowa pigs required a significant amount of money to maintain and subsequently breed. ${ }^{42}$ These pigs were pink and thus were called grimmelle but they were also more fragile than their predecessors earning them the name the "white princess;" these pigs required a wheat and vitamin based diet, regular baths, cement floors, veterinary interventions, and to make matters worse, they did not yield as many piglets as had been promised and the litters did not come often. 43 The new pigs brought conflicts to many towns because of the situation of those who had

\footnotetext{
${ }^{36}$ Alexander, 255

37 MacKenzie,

$38 \mathrm{Ibid}$.

39 Library of Congress - Federal Research Division, "Country Profile: Haiti, May 206," 05 2006, http://lcweb2.loc.gov/frd/cs/profiles/Haiti.pdf (accessed 0404, 2012). 10

$40 \mathrm{lbid}$.

${ }^{41}$ Bellegarde-Smith, 207

42 Ibid.132

43 Farmer, 208
} 
pigs and those who did not.44 In Dokay, a town in Haiti, for example, a priest known as Father Alexis had attempted to redistribute the pigs and piglets but was unsuccessful because they required too much maintenance, around $\$ 120-\$ 250$ was necessary per year for the upkeep of the pig and this was both an inconceivable and unrealistic demand as the average peasant lived on less than a dollar a day. 45

The persistent lack of government initiatives to improve and protect rural Haiti coupled with the eradication of ASF and the Haitian pig, as well as the increase of deforestation and the erosion of soil had drastic ramifications for agricultural employment. It was hardly surprising then, that by 2006 agriculture employed $46 \%$, of the country, the service sector now employed $44 \%$ of the population and there stood a $32.7 \%$ unemployment rate. 46 Four years later, the agricultural sector only employed $38.1 \%$ of the population and unemployment rose to $40.6 \% .47$ The decline in agriculture caused Haiti to import most of its foodstuffs most notably from the USA where in 2005, 35\% of its imports were from the USA. ${ }^{48}$ It also led many to migrate to the cities of Haiti most notably in Port-au-Prince as well as abroad to the USA and Canada where New York, Florida, Boston and Montreal where noticeably large diasporic community of Haitians began to settle. In Port-au-Prince, this further aggravated an already tense situation because of the over population of the city, in 2006, of a population of about 8.3 million, 1.5 million lived in the city Port-au-Prince. 49 As Haiti's population continued to augment so did the population in PAP and this caused great danger because many of the houses in Haiti were built on unsuitable lands such as hillsides and these houses were also poorly constructed. The overpopulation of PAP and the poor infrastructure of the capital city is the reason why the January 2010 earthquake had such a devastating effect to the lives of the citizens and to the infrastructure of the city. Again, in the face of such great calamity the government

\footnotetext{
44Ibid.133

$45 \mathrm{lbid}$.

46 CONSULAT GÉNÉRAL D'HAïTI À MONTRÉAL, L'economie Haitienne 2006

(Montreal, 2006).

http://www.haiti.org/images/stories/pdf/leconomie haitienne.pdf

47 CIA.GOV, The World Factbook, 04 3, 2012,

https://www.cia.gov/library/publications/the-world-factbook/geos/ha.html (accessed 04 4, 2012).

48 Library of Congress, 10

49 lbid.
} 
proved unable to help its own people and in the end it had to look abroad for aid.

The US and Haitian governments' cooperation in the early 1980 's to eradicate ASF is another example of the Haitian government's inability to put the interest of its population ahead of the interests of entities such as the USA. The USA led intervention to control and eliminate the ASF virus which further entrenched and devastated the already fragile and poor peasantry and Haitian economy. Although the agricultural sector of Haiti has decreased to an unprecedented low, hope may be restored if the government were to put its interest first, like the USA does so often, and begin a program to combat deforestation and replenish the soil of nutrients. Those who remain in the agricultural sector have been given some hope by the introduction of a new black pig by a group of French scientists..$^{\circ}$ These scientists bred some of the native pigs of Guadeloupe with another European breed and their offspring have been thriving in the environment of Haiti, and more importantly, they are black therefore the cultural sacrifice in voodoo ceremonies can now resume. ${ }^{11}$ However, the resurfacing of the black pig in Haiti cannot be the only solution to the declining peasantry. The Haitian government must begin to prioritize the development of rural Haiti if it wants to avoid the pressures of overpopulation in cities leading to catastrophes like the 300,000 deaths in 2010 in PAP. It is imperative for a government to take a stance like Toussaint's and initiate an agricultural program that will put the majority of the population first instead of continuing to work towards the interest of a few and only seeking to enrich themselves while in power. The question still remains however, when will the Haitian government stop betraying its population and actually govern responsibly? For any improvement depends strongly on the willingness of the government to work responsibly and respect its population to achieve any real change.

50 MacKenzie

$51 \mathrm{lbid}$. 


\section{Work Cited}

Alexander, Franz C. M. "Experience with African Swine Fever in Haiti." Annals of the New York Sciences, June 1992: 251-256.

Bellegarde-Smith, Patrick. Haiti: The Breached Citadel. Toronto: Canadian Scholar's Press Inc., 2004.

Berthold, Roland. Kombit a Haitian agricultural and economic system. http://www.haitimega.com/Agricultural Products and PracticesKombit a Haitian agriculture and economic system/855431807159 50112/article_86195166922211328.jsp (accessed 2012-04-04).

Bouguerra, Mohamed Larbi. Pour Sauver le Cochon Noir d'Haiti. http://www.pyepimanla.com/decembre-2008/articles/haiti-le-retourdu-cochon.html (accessed 01 21, 2012).

CIA.GOV. The World Factbook. 04 3, 2012. https://www.cia.gov/library/publications/the-worldfactbook/geos/ha.html (accessed 04 4, 2012).

CONSULAT GÉNÉRAL D'HAÏTI À MONTRÉAL. L'economie Haitienne 2006. Montreal, 2006. http://www.haiti.org/images/stories/pdf/leconomie haitienne.pdf

Dubois, Laurent. Haiti: The Aftershocks of History. New York: Metropolitan Books Hentry Hold and Company,LLC, 2012.

Farmer, Paul. "Swine Aid." In THe Haiti Files: Decoding the Crisis, edited by James Ridgeway, 130-133. Washington D.C: Essentiaal Books, 1994.

Food and Agriculture Organization of the United Nations. "Recognizing African Swine Fever: A field Manual." FAO Corporate Document Repository. http://www.fao.org/DOCREP/004/X8060E/X8060E00.HTM\#ch2 (accessed 03 31, 2012).

Haggerty, Richard A. Haiti: A Country Study. Country Studies, Washington: GPO for the Library of Congress, 1989. http://countrystudies.us/haiti/54.htm

James, C.L.R. The Black Jacobins. Second Edition. New York: Vintage Books Edition, 1989. 
James, C.L.R. "The San Domingo Masses Begin." In Caribbean Slavery in the Atlantic World: A Student Reader, edited by Hilary McD. Beckles Verene Shepherd, 946-960. Kingston: Ian Randle Publishers Limited, 2000.

Larose, Serge. L'exploitation Agricole en Haiti: Guide d'etude. Montreal: Centre de Recherche Caraibes, University of Montreal, 1976.

Larry E. Sullivan, R. Burke Johnson, Cynthis Calkins Mercado and Karen J. Terry, ed. Reagan Doctrine. Thousand Oaks: SAGE Publication, 2009.http://go.galegroup.com.myaccess.library.utoronto.ca/ps/i.do?id $=\mathrm{GALE} \% 7 \mathrm{CA} 11860822 \& \mathrm{v}=2.1 \& u=u$ toronto main $\& i t=r \& p=A O N E \& s w=w$ (accessed 03 31, 2012).

Library of Congress - Federal Research Division. "Country Profile: Haiti, May 206." 05 2006. http://lcweb2.loc.gov/frd/cs/profiles/Haiti.pdf (accessed 04 04, 2012).

MacKenzie, Debora. "Haiti, le retour du cochon." Pyepimanla. http://www.pyepimanla.com/decembre-2008/articles/haiti-le-retourdu-cochon.html (accessed 024,2012 ).

Mohammed-Ali, Kathleen. "“Vive Chef Coumbite!" THE NEW MASTERS IN POST-EMANCIPATION HAITI." Building Communities. http://scholar.library.miami.edu/emancipation/culture3.htm (accessed 04 4, 2012).

Prince, Rod. Haiti Family Business. London: Latin American Bureau (Research and Action) Limited, 1985.

"Reaganomics Revisited." Academic OneFile. National Review. 02 14, 1992.

http://go.galegroup.com.myaccess.library.utoronto.ca/ps/i.do?id=GALE $\% 7 C A 11860822 \& v=2.1 \& u=u$ toronto $m a i n \& i t=r \& p=A O N E \& s w=w$ (accessed 03 31, 2012).

Trouillot, Michel-Rolph. State Against Nation: The Origins and Legacy of Duvalierism. New York: Monthly Review Press, 1990. 